\title{
ARCHITECT LUZ VALENTE-PEREIRA: ARCHITECTURE, RESEARCH, AND LIFE IN A CHANGING COUNTRY
}

\author{
Patrícia Santos Pedrosa* \\ (D) https: / / orcid.org/0000-0001-9524-1437 \\ Lia Gil Antunes: \\ (D) https: / / orcid.org/0000-0002-5066-4062
}

\begin{abstract}
Luz Valente-Pereira (b. 1934, Lisbon) is a key figure of the $20^{\text {th }}$ century Portuguese History of Architecture, albeit a forgotten one. This research is a starting point for establishing a more solid biography of this pioneer who initiated the first decades of female participation in the architectural field in Portugal. After some professional experience in different contexts, she developed a stable research career at the National Laboratory of Civil Engineering (LNEC) with studies on various spatial scales. We have used different methodologies: bibliographical review, consultation of national archives, and an interview with her. Our proposal is not only to create female references but also to broaden the historical readings on women's participation in Portugal throughout the $20^{\text {th }}$ century.
\end{abstract}

Keywords: History of Architecture, research, women architects, Portugal.

\section{Resumo}

Luz Valente-Pereira: Arquitetura, investigação e vida num país em transformação

Luz Valente-Pereira (n. 1934, Lisboa) é um nome incontornável da História da Arquitetura portuguesa do século XX, embora tenha ficado na sombra. Esta pesquisa tem por objetivo ser um ponto de partida para fixar uma linha biográfica mais sólida de uma pioneira que iniciou as primeiras décadas de participação feminina na arquitetura em Portugal. Depois de algumas experiências profissionais, desenvolveu uma estável carreira na investigação no Laboratório Nacional de Engenharia Civil (LNEC) com estudos sobre diversas escalas espaciais. Diferentes metodologias foram aplicadas: revisão bibliográfica, consulta de arquivos nacionais e uma entrevista a Luz Valente-Pereira. A proposta é não só a criação de referências femininas, mas também a ampliação de leituras históricas sobre a participação das mulheres em Portugal no século XX.

Palavras-chave: História da Arquitetura, investigação, arquitetas, Portugal.

* Centro Interdisciplinar de Estudos de Género do Instituto de Ciências Sociais e Políticas da Universidade de Lisboa - CIEG/ISCSP-ULisboa, 1300-666 Lisboa, Departamento de Engenharia Civil e Arquitetura da Universidade da Beira Interior (Deca-UBI, 6201-001 Covilhã), Portugal. Endereço postal: Rua Almerindo Lessa, Gab 7 | Bloco Tejo | Piso - 1 - 1300-663 Lisboa, Portugal. Endereço eletrónico: pat.pedrosa@gmail.com

* Centro Interdisciplinar de Estudos de Género do Instituto de Ciências Sociais e Políticas da Universidade de Lisboa - CIEG/ISCSP-ULisboa, 1300-666 Lisboa, Portugal.

Endereço postal: Rua Almerindo Lessa Gab 7 | Bloco Tejo | Piso - 1 - 1300-663 Lisboa, Portugal. Endereço eletrónico: liapantunes@gmail.com 


\section{Resumen}

Luz Valente-Pereira: Arquitectura, investigación y vida en un país en transformación

Luz Valente-Pereira (n. 1934, Lisboa) es un nombre ineludible de la Historia de la Arquitectura portuguesa del siglo XX, aunque en la sombra. Esta investigación pretende ser un punto de partida para establecer una línea biográfica más sólida de una pionera que inició las primeras décadas de participación femenina en la arquitectura en Portugal. Después de algunas experiencias profesionales, desarrolló una carrera estable en la investigación en el Laboratorio Nacional de Ingeniería Civil (LNEC) con estudios en varias escalas espaciales. Se aplicaron diferentes metodologías: revisión bibliográfica, consulta de archivos nacionales y una entrevista a Luz Valente-Pereira. La propuesta no es solo la creación de referencias femeninas, sino también la expansión de lecturas históricas sobre la participación de las mujeres en Portugal en el siglo XX.

Palabras clave: Historia de la Arquitectura, investigación, arquitectas, Portugal.

\section{Introduction}

Researching new subjects and approaches is a demanding and challenging task. This text stems from this contradictory place: if we have not yet established basic research regarding the history of women architects in Portugal, how can we produce a critical and intersectional reflection? The broader scope of the research project «W@ARCH.PT Women Architects: Building Visibility, 1942-1986» ${ }^{1}$ is an attempt to begin writing the history of women architects in Portugal systematically and coherently. The lines of action are various and complex, and so is the group being studied. On the one hand, understanding why and how women - as a diverse group - disappear from Architecture, and developing a feminist historiography in Architecture. ${ }^{2}$ On the other hand, recovering names, works and contributions: not only from women architects commonly associated with the practice of architectural design but also from those who followed diverse professional paths inside and outside the discipline, or who were unable to complete their training. Writing women's biographies means countering their lack of recognition as active historical subjects and, consequently, the dearth of references for new generations. Biographical articles remain relevant, especially in the construction of the History of Women. Although this work focuses on an «exceptional woman», the wider research project highlights the diversity and complexity of women's lives as a heterogeneous group. Archival work and the gathering of oral testimonies are crucial methods if we want to understand the role

W@ARCH.PT is a research project funded by the Portuguese Foundation for Science and Technology (FCT), which has been developed since 2018 at the Research Centre on Gender Studies (CIEG-ISCSP) of the University of Lisbon.

2 On the feminist historiography underpinning the W@ARCH.PT, see Pedrosa (2019). 
of Portuguese women architects, ${ }^{3}$ expanding the narratives on architectural culture in Portugal. Considering the lack of research on this topic and the need to achieve historical justice, this article arises as a starting point for locating Maria da Luz Valente-Pereira in her field of action and tracing her biographical and professional path. The main source of information was our interview with her (Valente-Pereira 2019), ${ }^{4}$ coupled with archival material and the bibliographical review of her publications. The work of other researchers on similar issues and the history of the National Laboratory of Civil Engineering (LNEC) have also been taken into account.

In Portugal, the production of knowledge related to architecture and the city began much later than in nearby countries. The construction of these bodies of historical, theoretical and critical knowledge became more established in the 1960s with the works of Nuno Portas (b. 1934) or Pedro Vieira de Almeida (1933-2011), among others. The intensification of the relationship between Portuguese architects and international colleagues, mostly from Southern Europe, as well as the emergence of a generation of architects with growing critical and social awareness, led to a change in the production of theoretical, critical and historical discourses mainly focused on the issues of dwellings. The main paradigm shift relates to the emergence of critical thinking, in contrast to the opinionated discourse usually found in the Portuguese context (Pedrosa 2010).

Although her extensive work is unfairly unknown and unstudied - both within the Portuguese History of Architecture and academic courses -, the architect Luz Valente-Pereira (b. 1934, Lisbon) was part of an emerging group of researchers of architecture and the city. Her work spans over four decades of Portuguese history (Figure 1). Born during the Estado Novo dictatorship (1933-1974), hers is the story of a young woman whose university education and initial professional experiences took place in the context of an authoritarian regime. ${ }^{5}$ Between those long years and the introduction of democracy in Portugal on 25 April 1974, she developed extensive, diverse and robust research at the LNEC, ranging from housing to broader issues such as cities and urban and regional planning.

3 For a general framework on the contexts of women architects in Portugal, see Pedrosa (2015), Antunes (2016), Pérez-Moreno and Pedrosa (2020). For biographies of Portuguese women architects, see Roxo (2016), Carvalho (2020), Milheiro and Fiúza (2020).

4 The interview with Luz Valente-Pereira, conducted by Patrícia Santos Pedrosa and Lia Gil Antunes, was recorded - audio and video - on 20 December 2019, in the architect's house in Alenquer. It lasted approximately four hours and was partially transcribed. We have chosen an open-ended type of interview, with questions aimed at establishing previously gathered information, as well as information provided by the interviewee herself. Given the interviewee's advanced age, her husband has helped clarified a few chronological imprecisions.

5 For more information on the conditions of Portuguese women, see, for example, Pimentel (2011), Tavares (2011), Pimentel and Melo (2015). 
Figure 1.

Synthesis of the academic and professional path of Luz Valente-Pereira crossed with political regimes in Portugal. Source: Research project W@ARCH.PT - Women Architects in Portugal: Building Visibility, 1942-1986.

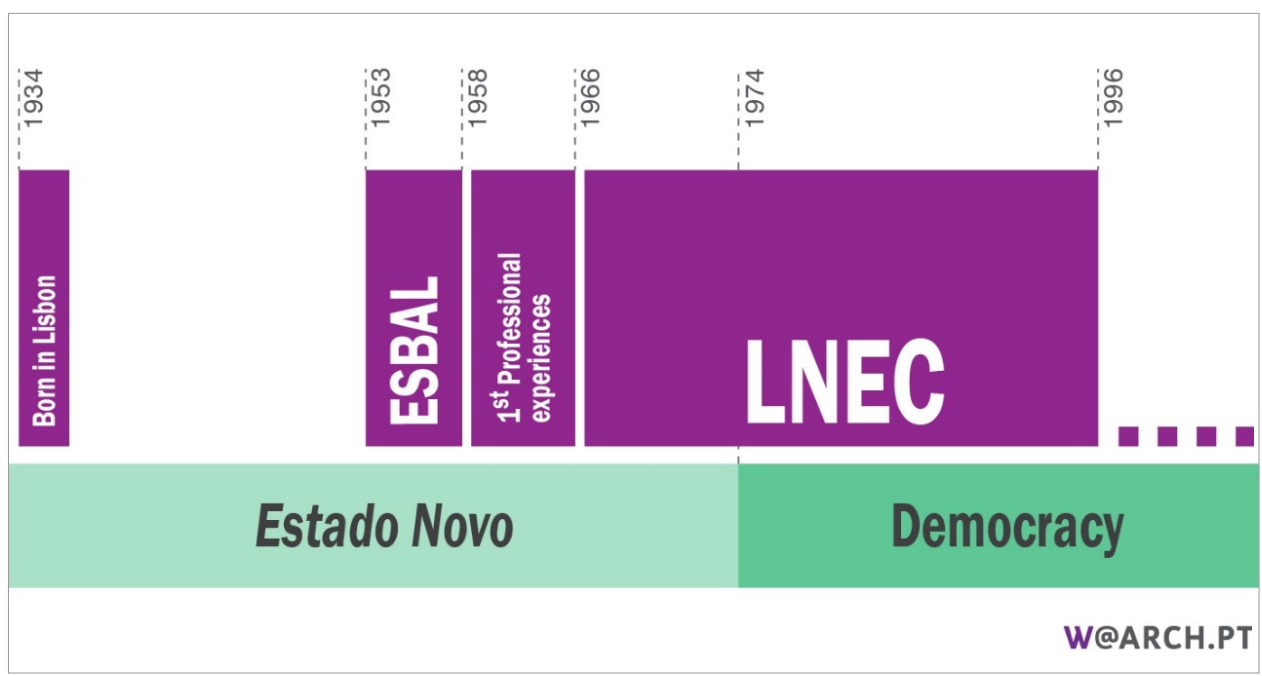

\section{Architectural Education and Initial Professional Experiences}

Born in a traditional bourgeois family, Luz Valente-Pereira (Figure 2) was encouraged from an early age to value independence, responsibility, and freedom. In her own words, she was 'educated as a man', excused from household duties to study, which was 'her only obligation', to 'acquire the ability to express herself, to be useful, to know how to solve problems through an activity [and] to be independent' (Valente-Pereira 2018, 40). However, when referring to these years of early education, she underlines that 'it was essential to respect the socially correct and, for a girl, it was, above all, important to behave to avoid creating a bad reputation' (Valente-Pereira 2018, 40).

In her youth, she attended drawing classes, where she met extraordinary people such as the Portuguese writer and poet Natália Correia (1923-1993). She claims to have chosen to study architecture without conviction: on the one hand, nothing else interested her; on the other hand, she liked arts and drawing. With only a feeble idea about the meaning of the architecture profession and, amid the Estado Novo dictatorship, she started an Architecture degree at the School of Fine Arts in Lisbon (ESBAL) in 1953, completing the course units five years later (Valente-Pereira 2018, 40). 
Figure 2.

Photo of Luz Valente-Pereira during the interview conducted by the research project W@ARCH.PT, on 20 December 2019 (Valente-Pereira 2019).

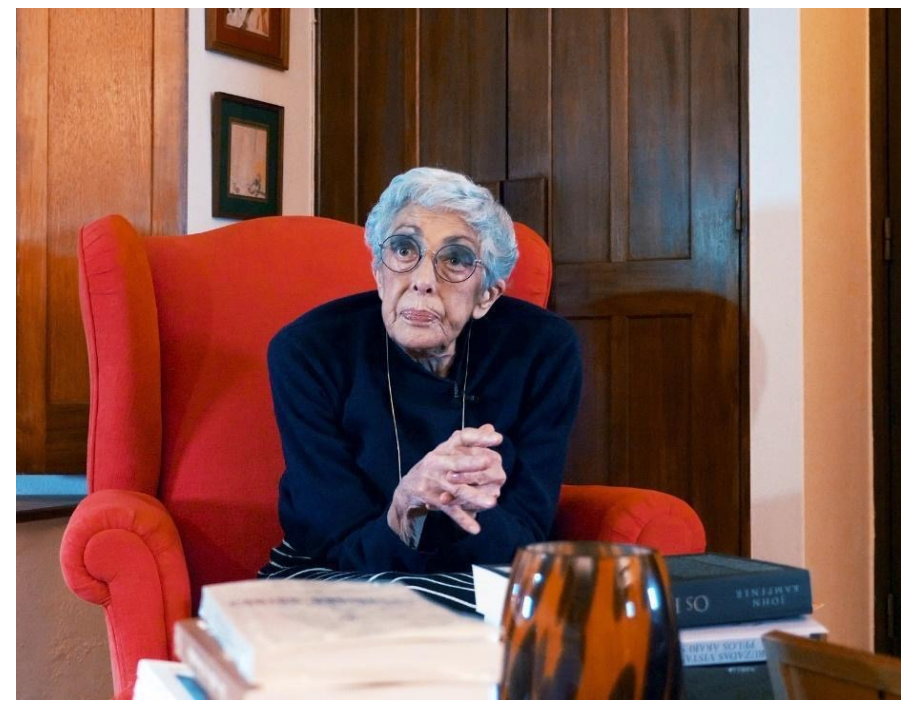

After finishing the academic part of the architecture degree, she completed pedagogical subjects at the Faculty of Arts and Humanities of the University of Lisbon, which allowed her to teach drawing in high school. This experience proved to be unstimulating and, consequently, she immediately returned to architecture. During a stay in Porto, she became aware of international opportunities and decided to take a risk. In the early 1960s, she worked for a year at the French studio Société d'Études Techniques et d'Aménagements Planifiés, where she collaborated with one of the founders, the French architect and urbanist Guy Lagneau (1915-1996). During this experience, she lived in Paris and spent some time in Africa, where she developed a project proposal for a village in the Abidjan region of the Ivory Coast. On her return to Lisbon, she joined the studio of the Portuguese architect Nuno Teotónio Pereira (1922-2016). Her collaboration in this architectural studio focused mainly on single-family housing projects. Here, she had direct contact with architectural design practices and she soon realized that she was not interested in this type of work.

Looking for other experiences and challenges within the discipline, she secured an annual scholarship from the United Nations and the opportunity to reflect on the problem of growth and planning in 'developing countries'. With this goal, she attended a postgraduate course in Regional Planning and Development at the Institut de Recherche et Formation en Vue du Développement Harmonisé, in Paris, between 1962 and 1963. This highly interdisciplinary course also allowed 
her to meet people from all over the world. When she returned to Portugal in 1963, she was invited to participate, for two years, in the team of the Aveiro Regional Plan, which was coordinated by the French architect and urban planner Robert Auzelle. Valente-Pereira's skills and urban knowledge were put to good use in the preparation of the Master Plan for the City of Lisbon (1965-1966). Here, she mainly focused on the necessary surveys. As she referred in the interview, these experiences in urban planning also proved unrewarding (Valente-Pereira 2019).

\section{Research Career at the LNEC - The Scale of Dwellings}

The course of her professional life changed in 1966. Between June 1966 and March 1996, at the LNEC in Lisbon, she established a stable career in research, obtaining a specialist degree and the position of research coordinator. After all the professional experiences mentioned above, she found the joy of 'being paid to study' (Valente-Pereira 2018, 42). Over these three decades, she extended her architectural studies to urban sociology and, particularly, to the issues of urban housing, form and rehabilitation. She has represented the LNEC and Portugal in numerous international, technical and scientific meetings. Our interview with her allowed us to discover and deepen some aspects of her work that had not been previously charted - for example, her conferences in Brazil, France, Belgium and Italy (Valente-Pereira 2019).

In 1962, Nuno Portas joined the LNEC as Head of the Construction and Housing Division and later teamed up with Luz Valente-Pereira and Francisco David Carvalho da Silva Dias (Carvalho 2012, 47). Regarding the creation and first years of the small architecture research centre at the LNEC, Portas ${ }^{6}$ said:

we went there as architects. Then I brought Maria da Luz Valente-Pereira, who was extraordinary, [...] she was almost always the one who conducted the surveys. [She] treated the more sociological questions, since at one point she devoted herself to urban sociology and worked directly with sociologists. (Carvalho 2012, 291)

Luz Valente-Pereira and Portas conducted ground-breaking work. They were regularly active in researching and proposing solutions not only for housing problems beyond a physical dimension, but also for the complexities of urban life and form. ${ }^{7}$ Mariana Carvalho wrote about the well-renowned Portas in the context of the LNEC, mentioning that

for the first time there was a group of architects in Portugal that guaranteed the necessary conditions for carrying out an investigation of architectural interest.

Interview with Nuno Portas in March 2011, carried out by the architect Mariana Carvalho (2012). These questions had been under discussion internationally since the 1950s, at least. Despite the constraints of the dictatorship, Portuguese architects were able to access part of these discussions. 
In this way, through population surveys, Nuno Portas, together with Maria da Luz Valente-Pereira, an intern architect, sought to gather conclusions about the 'lifestyle' and tastes of the respondents, who lived in so-called social housing. (Carvalho 2012, 111)

This group was part of the Centre for Architecture and Urbanism (NAU) at LNEC, which established a 'long tradition of research in architecture' (LNEC 2011, 1). Concerning urban studies, a new group emerged in $1987,{ }^{8}$ which included Luz Valente-Pereira, Fernando Gonçalves and Vitor Campos. Later, the group was dissolved and these researchers re-joined NAU (2011).

The revolutionary studies of Luz Valente-Pereira allowed analyses and diagnoses that supported the definition of residential quality. These have made it possible to understand the activities performed at home and the availability of space, as well as the organization and satisfaction provided by different types of dwellings. In addition to the constructive, architectural and urban approach, the perceptions and uses of the inhabitants' spaces became part of the project, namely the analysis of residential satisfaction, well-being, and symbolic dimensions, such as the use and appropriation of residential areas (Freitas, Menezes, and Coelho 1996). This research with strong links to social aspects resulted in a series of reports concerning the everyday lives of people within an urban environment. This research project, co-authored by Portas, includes surveys of family needs in terms of urban housing (Portas and Valente-Pereira 1967). Applied to national social housing needs, they identified what activities were performed inside the house and how houses should be equipped, organized and sized, as a way of guaranteeing the best living conditions. In 1967, Luz Valente-Pereira produced a document that outlined the classification, designation and minimum requirements for social housing in urban centres. Some observations and ideas taken from this research were summarized in an article published in 1968 in the newspaper Diário de Lisboa ${ }^{9}$ (Figure 3), i.e., they were shared with the general public. Based on the questions, 'Do the houses that we build satisfy residents?' and 'What houses should be built?' (Valente-Pereira 1968, 4), Luz Valente-Pereira was able to critically comment on the notion of minimum in housing and to study the activities that take place at home and/or in public space/urban furniture, the organization of houses and their uses, and the need to define satisfactory minimum programs. In the context of a complex topic, she offered some clues regarding housing planning, stressing that houses should follow the evolution of living standards - sociocultural and technicaleconomic - and of the family itself. Rising up to these challenges, she pointed out the importance of the 'elasticity of dwellings', related to the degree of mobility of families and the need to know the existing reality (Valente-Pereira 1968, 6).

Urbanism and Municipal Planning Group.

This was part of a series of works on Architects and Urbanism organized by the Portuguese Union of Architects in collaboration with Diário de Lisboa. 
Figure 3.

Excerpt from the text «As casas que se constroem» [The houses that are built], by Luz Valente-Pereira, published in the newspaper Diário de Lisboa, Lisbon, Portugal, August 8, 1968 (Valente-Pereira 1968, 4).

\section{As casas qua se constroem}
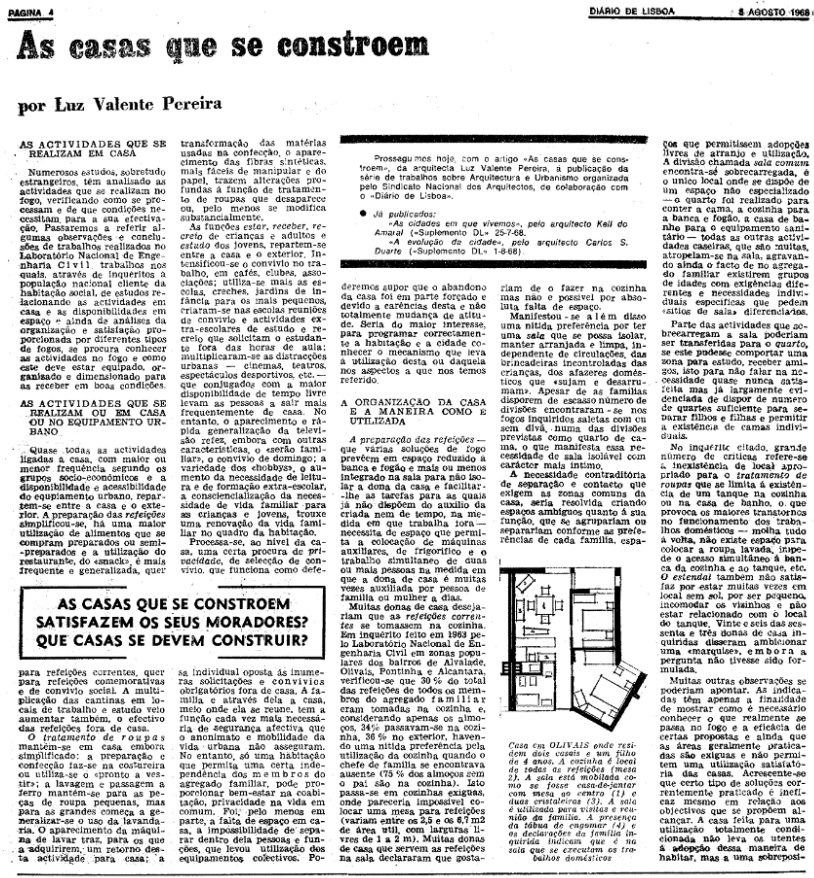

In the early 1970s, Luz Valente-Pereira resumed and developed the survey on urban housing by questioning the issue and design of methodologies (ValentePereira and Gago 1972, 1974a, 1974b; Valente-Pereira 1977a, 1977b, 1977c). When designing, analysing and evaluating survey data, more than knowing what area was suitable for a particular household, it was crucial to know what led each individual to use a particular space and how it was used. Among other relevant conclusions, Luz Valente-Pereira highlighted two main ideas. On the one hand, that a house must be adaptable and malleable to the circumstances of each family and inhabitant; on the other hand, that this type of study has actively, and for a long time, been used by the modernists to justify minimal and inflexible spaces, especially in so-called social housing for the disadvantaged populations (ValentePereira 2019).

In July 1970, with some professional experience under her belt, Luz ValentePereira presented the final project to earn her degree in architecture. Drawing on the aforementioned studies, she officially concluded her training as an architect. Her research intensified throughout that decade. In 1977, she published several surveys 
on the use and space of houses (Valente-Pereira 1977a, 1977b, 1977c). These reflections continued and, alongside the sociologist Maria Amélia Baptista Corrêa Gago, she focused on field research concerning building planning. They then synthesized the sample's characteristics and the conclusions of these surveys in a publication (Figure 4) on the use of space in dwellings (Valente-Pereira and Gago 1974c).

Figure 4.

Page of the book O Uso do Espaço na Habitação [The Use of Space in the Household], showing 'Example 1 - Table of activities - meals' and 'Example 2 - House plan'

(Valente-Pereira and Gago 1974c, 4).

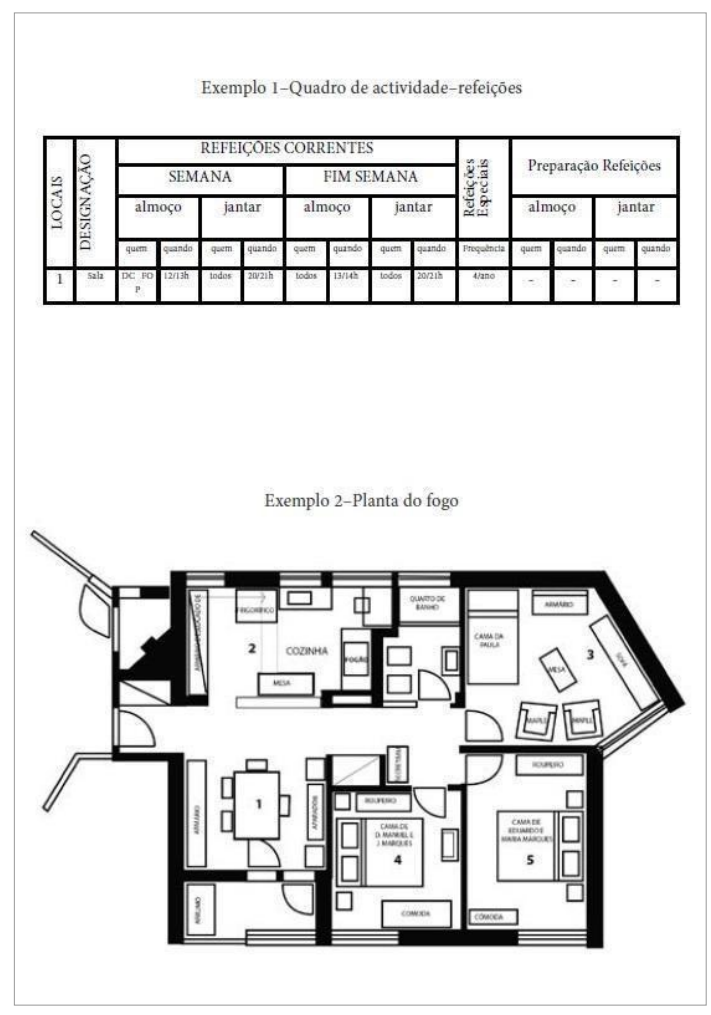

\section{Research Career at the LNEC - The City Scale}

Luz Valente-Pereira's studies began to expand from housing issues to the complexities of urban spaces. ${ }^{10}$ Realizing the relations between the uses of interior 10 We can find a similar path - from dwellings to the city - in the work of Nuno Portas (See, for
example: 1964 and 2003-2011). 
and exterior spaces, the house and the city, she designed and carried out a survey on the use of the city (Valente-Pereira 1971a) ${ }^{11}$ (Figure 5). In 1971, she applied for an expert position as the LNEC with a proposal for an urban system model (Valente-Pereira 1971b). This work resulted from her previous research. ${ }^{12}$ Following the international debate on architecture, she applied a mathematical model to the analysis of the city, supported by the Theory of Systems. The aim was to 'represent the urban system so that one can obtain and manipulate the necessary information to intervene in it, thus programming alternative project proposals for the construction of urban space' (Valente-Pereira 1973, 5). As she commented in the interview (Valente-Pereira 2019), this study allowed her to achieve two main goals, as well as criticize this deterministic approach: on the one hand, to establish relationships and understand the complexity of the urban reality; on the other hand, to prove that mathematical models are not sufficient to encompass the full diversity of urban life, i.e., they are unable 'to capture the city' (Valente-Pereira 2019). Following these studies on urban relations, she was invited to conferences (Jornal do Brasil 1972, 19) and to promote the specialization course 'Urban architecture: methods and criteria for design', in Brazil, in 1972 ${ }^{13}$ (Figure 6). As Luz Valente-Pereira referred, besides being well-attended, this event led a few Brazilian universities to incorporate her publications into their syllabuses - which is yet to happen in Portugal (Valente-Pereira 2019).

After the restoration of democracy brought by the Carnation Revolution on 25 April 1974, Luz Valente-Pereira transposed the issues discussed in Brazil to European contexts - for example, Liège, Strasbourg and Nancy - and was surprised to find out that they were still relevant in starkly different geographical, social and economic realities. In Portugal, given the accumulated knowledge and data on housing issues, she participated - albeit discreetly - in the Local Ambulatory Support Service, better known as the SAAL Process (1974-76). ${ }^{14}$ José Bandeirinha (2011) analysed this moment accurately. He referred that the joint project meetings ${ }^{15}$

11 This study later led to the book The Use of the City-A study on the City of Lisbon (Valente-Pereira 1990).

12 She also published the entire process: the preparation of the survey (Valente-Pereira 1971c), the collection and analysis of data, as well as the design of analytical methods and plans (ValentePereira 1971d). The conception of a pilot survey on the use of the city and the application of a model of analysis of urban behaviors would later structure a dynamic model of analysis of the urban system applied to the urban scale (Valente-Pereira 1973).

13 The course was repeated in 1973 and 1974 (Universities of Brasília, São Paulo and Rio de Janeiro). Luz Valente-Pereira underlined the fact that they always took place during her holidays, since the LNEC did not want to be institutionally involved in them (Valente-Pereira 2019).

14 SAAL - Serviço de Apoio Ambulatório Local was a renovation process of the Portuguese housing stock aimed at disadvantaged populations, in which the inhabitants participated.

15 These meetings focused on the presentation of projects and the preparation of several studies on three main topics: (i) bureaucratic aspects, (ii) technical and economic aspects and (iii) political aspects. 
Figure 5.

Cover of the book A Utilização da Cidade: um estudo sobre a cidade de Lisboa [The Use of the City. A Study on the City of Lisbon] (Valente-Pereira 1990).

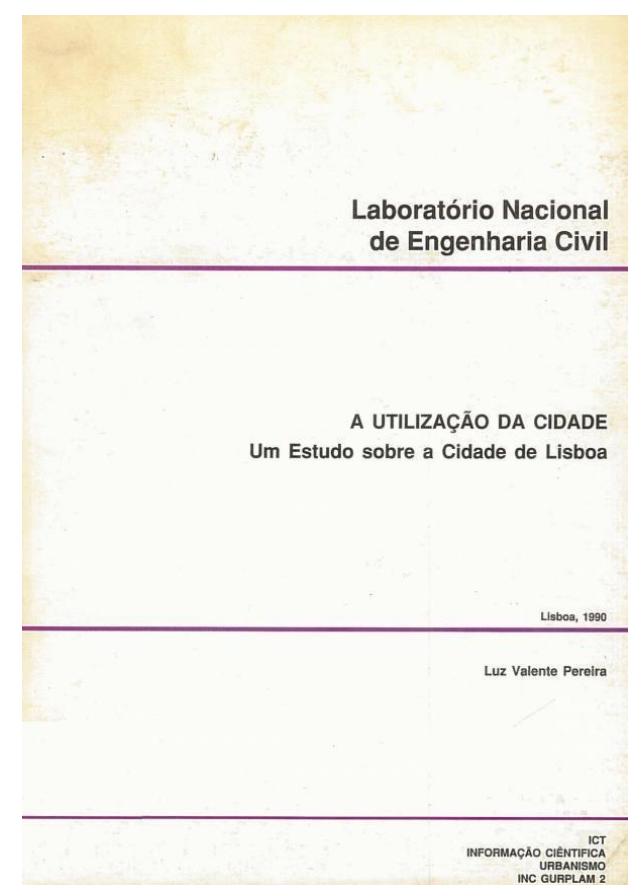

had the 'participation of technicians from the brigades, services, FFH [Fundo de Fomento da Habitação, Housing Development Fund] and other organizations'. This participation included 'figures such as Abel Reina, Fernando Bagulho, José Miguel da Fonseca, Cruz Henriques, João Gomes Horta, Teresa Sá and Luz ValentePereira' (Bandeirinha 2011, 196). These architects included a group of experts considered 'elements of direct support', who, according to Bandeirinha,

proposed the creation of a new regulatory body for the development of projects, which stemmed from the confrontation between SAAL's action and the action of other urban players (and corrected the latter). They believed that the General Regulation on Urban Buildings (RGEU) in effect at the time was 'outdated and completely inadequate' and felt that SAAL's operations should be developed 'outside of any prior regulation that was external to the process'. (Bandeirinha 2011, 210)

After her admission to the Association of Portuguese Architects - member 1685 - in 1981, Luz Valente-Pereira participated in the 2nd Congress of this organization under the theme 'The Architects and Spatial Planning'. During the 


\section{Figure 6.}

Newspaper article 'Arquiteta portuguesa diz que não existe receita para construção de cidade' [Portuguese female architect says there is no recipe for building a city], published in the urbanism section of the newspaper Jornal do Brasil, September 24, 1972, reporting on the conference by Luz Valente-Pereira at the School of Architecture of the Federal University of Minas Gerais, Brazil, on the goals and methods of analysing urban space (Jornal do Brasil 1972, 19).

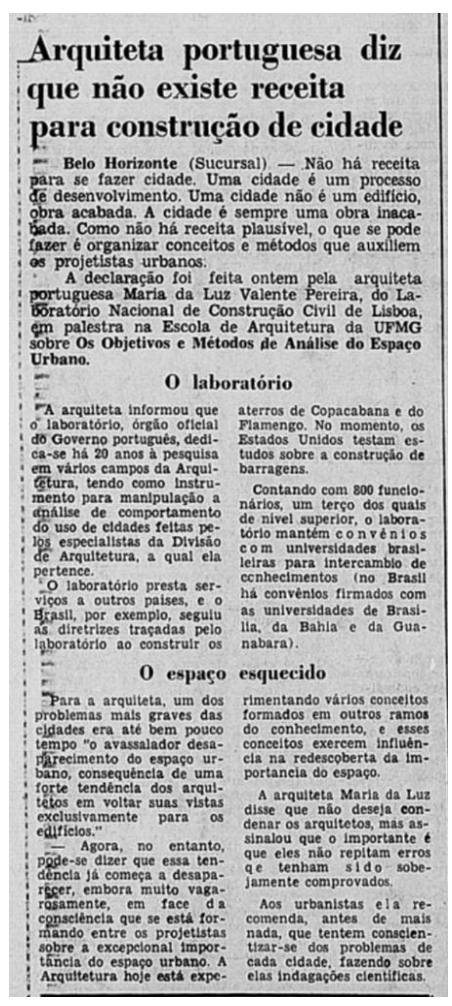

event held at the LNEC, in Lisbon, between 12 and 15 November 1981, Luz Valente-Pereira focused on the 'urban space as an architectural object - consequences in terms of planning, design and professional practices' (Valente-Pereira 1981a). The 1980s brought about new contexts and professional challenges for Luz ValentePereira, not only due to the instability that marked the consolidation of democracy but also the departure of Nuno Portas from the LNEC. ${ }^{16}$ Between 1979 and 1982,

16 In 1974, Portas assumed the role of Secretary of State for Housing and Urbanism onj the 1st Provisional Government. Therefore, the organization was left with no leader. As Valente-Pereira mentioned, even though she had no interest in it, no invitation was made to her (Valente-Pereira 2019). 
Luz Valente-Pereira became a consultant for the FFH as a result of her professional experience in the previous decades, as well as her ability to merge various thematic scales. At this stage, as she highlighted in the interview, she also worked as a consultant for the team of the Almada-Monte da Caparica Integrated Plan. She found an empty and expectant public land with a modernist plan divided into three large areas occupied by different views of the city belonging to each of the three architects involved. ${ }^{17}$ Through critical reflections to connect these interventions, Luz Valente-Pereira raised issues concerning the construction processes of the city, while consolidating questions about what the urban form is and how it is defined (Valente-Pereira 2019).

When we analysed Luz Valente-Pereira's research from the 1980s to the mid1990s, we found three essential axes. First, the urban form, ${ }^{18}$ its definition and key concepts (Figure 7) (Valente-Pereira 1982, 1983a, 1987a); second, urban rehabilitation, ${ }^{19}$ on which she wrote a seminal work (1987b); finally, urban, municipal and regional planning..$^{20}$ The various problems raised by municipal planning led to the establishment of the foundations of a methodological renewal (Valente-Pereira 1984a), the development of essays on the policies and strategies of municipal action $^{21}$ and the design of a Method for the technical support of the socio-urban development of an area of urban intervention (Valente-Pereira 1986b). ${ }^{22}$ The critical questioning of the myriad facets of urban planning surpassed the scope of the research. Luz Valente-Pereira collaborated from its inception in the Plan to Safeguard the Old Centre of Sacavém, ${ }^{23}$ both as a consultant and project coordinator (Figure 8). Invited by Maria João Gonçalves, the municipal architect, Luz Valente-Pereira was able to assess the applicability of the previously studied methods in a real-life situation. Although the project was short-lived and ended without any political commitment, during the interview, Luz Valente-Pereira praised the teamwork of the technical council group and the involvement of the population - residents and business owners - in discussions and events ${ }^{24}$ (Valente-Pereira 2019). The professional career of Luz Valente-Pereira ended in 1996, when she retired and left LNEC.

Project team: João Paciência, Vasco Costa and João Andrade.

18 These publications were later recovered; see, for example, Marat-Mendes, Almeida, and Borges (2019).

19 See also Valente-Pereira (1991, 1994).

20 On this topic, she also published: Valente-Pereira (1981b, 1983b, 1986a).

$21 \quad$ See, for example: Valente-Pereira (1984b).

22 Technical information composed of two volumes dedicated, respectively, to the methodology (Valente-Pereira 1986b) and the planning and programming of short-term interventions (Valente-Pereira 1987c).

23 As she remarked in the interview, the initial challenge for the meta-plan was a free and quick first approach to the characteristics of the predefined territory and the constraints of the project itself, without a 'limiting program' (Valente-Pereira 2019).

$24 \quad$ Events such as the car-free day in Sacavém's city centre.
} 
Figure 7.

Cover of the book Arquitectura Urbana [Urban Architecture] (Valente-Pereira. 1987a).

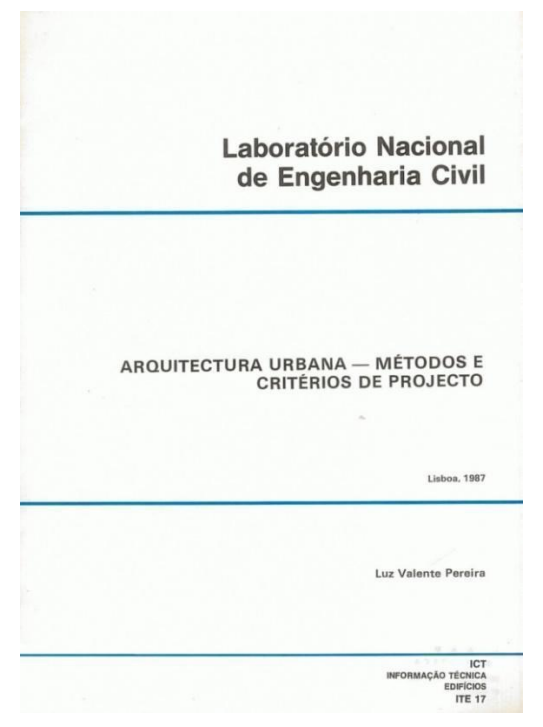

Figure 8 .

Pages of the book Urban Rehabilitation - The Reading of the Urban Image, (a) about the reading approach to the area and (b) the composition and morpho-typological structure of urban spaces in the «Plan to Safeguard the Old Centre of Sacavém» (Valente-Pereira, n.d., 25, 68).

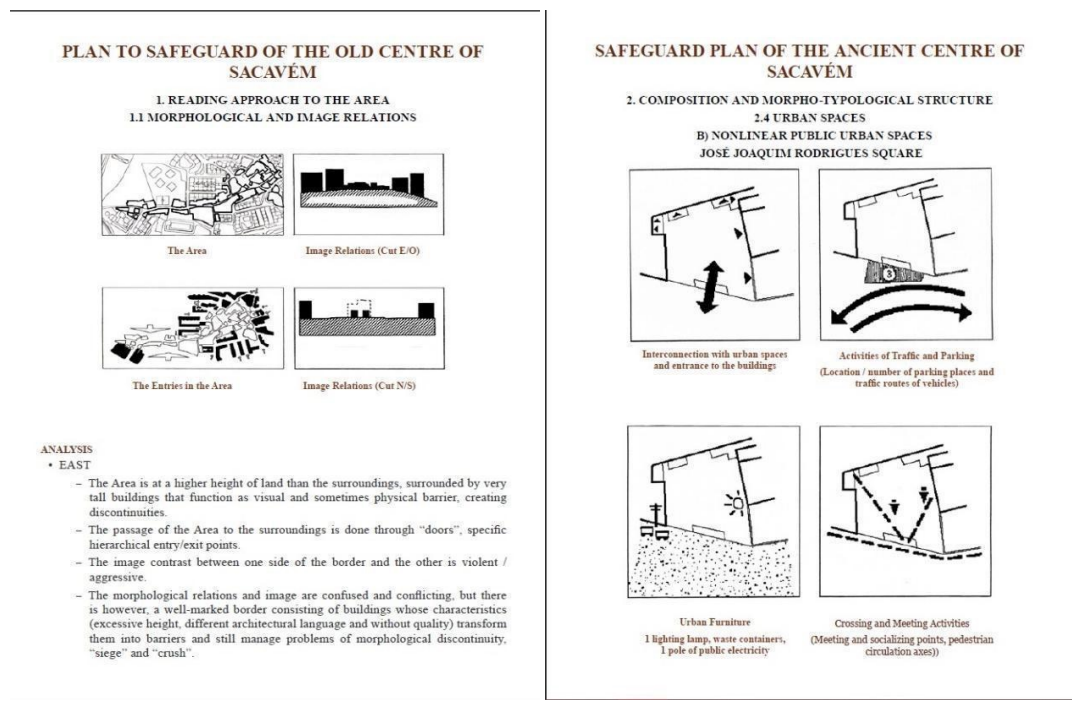




\section{Some final notes}

The wealth of Luz Valente-Pereira's path, as well as the wide range of critical questions and perspectives through which it can be approached, are far from being resolved in this article. As mentioned earlier, we have tried to contribute to a beginning. Nonetheless, as final notes, we would like to propose a few reflections that result both from the biographical work developed and the prospective questions that have emerged.

The objects of study that she has chosen throughout her career - from the house to the city - and the concerns that have moved her can be placed into a wider Portuguese context of reflection and research in Architecture. Despite finding a place in her time, and considering the extensive and relevant scientific production carried out in the LNEC for five decades that were presented above, it is clear that she is rarely referenced or cited in scientific and academic architectural works. Her absence is also evident in historical records of $20^{\text {th }}$ century Portuguese Architecture.

Oral narratives emerge as an important source of information and problematization for the construction of the History of Women. For example, the analysis of the interview has allowed us to realize that the autonomy and independence economic as well - that was imparted to Luz Valente-Pereira from early on marked her personal and professional lives. As a young woman during the Portuguese dictatorship, she studied at the university, got a degree in Architecture and traveled abroad by herself. Upon her return, she had various professional experiences before finding out what truly motivated her. It is important to underline, however, that if in the interview she provided an exhaustive chronological list of her professional achievements, there were very few comments on her personal life or the key moments that characterized the lives of so many women of her generation. What one decides to talk about or not is also an element that invites reflection.

Moreover, from a reflection on the studied material, an interesting paradox emerged, to a certain extent linked to the previous point. During the interview, Luz Valente-Pereira did not mention situations of obvious discrimination, and certainly not connected to the fact that she is a woman. ${ }^{25}$ In a few moments, she referred her non-confrontational character as an explanation for any attempts to silence her. In certain occasions she chose to act outside of the LNEC, as a way of obtaining international appreciation and visibility for her work. For example, she funded the Brazilian conferences herself, which took place during her holidays, as well as the belated translation of some of her works into English. Even though we

Another important question needs to be developed further: did her privilege as a white, graduated, middle-class woman, living in the country's capital, educated for professional and personal autonomy, hindered an awareness of the gender discrimination to which she might have been subjected? This reflection is vital and pertains to every woman architect, given the traditionally elitist character of the profession. 
can sense some acceptance of the fact that her work was not recognized by her peers, the aforementioned reactions arise as acts of discreet rebellion against an imposed silence. In a way, the strategy that she chose to overcome a professional reality that was felt as disadvantageous led to a greater personal investment, aligned with her idea of independence.

The visibility of Luz Valente-Pereira's professional path demands a critical reflection on the mechanisms of omission and silencing of History. Subsequent studies should focus on her life and work, but also on the full, complex, contextual and diverse History of Women in Architecture in Portugal. Luz Valente-Pereira was probably the first woman architect in Portugal to devote herself exclusively to a career in research. She is part of an extensive group of architects who, working outside architectural studios and shunning the limelight, were essential in the construction of architectural knowledge, even though they are not part of Portuguese historical narratives yet. As mentioned before, this biographical article is a contribution to future critical works, both produced within History, or coming from complementary scientific perspectives, such as urban studies, sociology or the theory of architecture. Awarding her visibility also means awarding visibility to research work as a relevant professional practice in the construction of Portuguese architectural culture, focusing on something other than the project practice. We are still yet to understand the true repercussion of these studies and proposals residential, urban and territorial - in the improvement of the conditions of spatial justice, as the materialization of democracy and full citizenship in Portugal.

\section{Acknowledgements}

This research and the translation of this article was supported by Portuguese national funds through Fundação para a Ciência e a Tecnologia (FCT), under project PTDC / ART-DAQ/32388/2017.

\section{References}

Antunes, Lia Gil. 2016. «Questões de género em arquitetura. História(s), espaço(s) e experiências profissionais e arquitetónicas». ex aequo 33: 67-81. DOI: https:/ / doi.org/ 10.22 355/ exaequo.2016.33.05.

Bandeirinha, José António. 2011. O Processo SAAL e a Arquitectura no 25 de Abril de 1974. Reprint. Coimbra: Imprensa da Universidade de Coimbra. DOI: https://doi.org/ 10.14195/978-989-26-1265-2.

Carvalho, Filipa Reis. 2020. Maria José Marques da Silva. Uma arquiteta pioneira em Portugal. Master Thesis in Architecture, Department of Architecture, University of Coimbra.

Carvalho, Mariana Marques Ramos Rodrigues. 2012. Investigação em Arquitectura: O Contributo de Nuno Portas no LNEC: 1963-1974. Master Thesis in Architecture, Department of Architecture, University of Coimbra. 
Freitas, Maria João, Marluci Menezes, and António Baptista Coelho. 1996. «Contributos Sociológicos para a Análise e Definição de Qualidade Residencial». Paper presented at the III Portuguese Congress of Sociology: Práticas e Processos de Mudança Social, Lisbon, February 7-9. Available at https://aps.pt/wp-content/uploads/2017/08/ DPR492abea138282_1.pdf.

Jornal do Brasil. 1972. "Arquiteta portuguesa diz que não existe receita para construção de cidade», 1. ${ }^{\circ}$ Caderno - Urbanismo, 19. September 24, Year LXXXII, 157th edition. Available at http: / / memoria.bn.br/DocReader/030015_09/67772.

LNEC- Laboratório Nacional de Engenharia Civil. 2011. Núcleo de Arquitectura e Urbanismo (NAU) do LNEC - Áreas de intervenção. Lisbon: LNEC. Available at http:/ / repositorio. lnec.pt:8080/jspui / handle/123456789/1001862.

Marat-Mendes, Teresa, Patrícia Bento d'Almeida, and João Cunha Borges. 2019. «Mapeamento de Conceitos e Paradigmas para a Sustentabilidade». Researchers meeting with Science and Technology presented at the Ciência '19, Lisbon Congress Centre, July 8.

Milheiro, Ana Vaz, and Filipa Fiúza. 2020. «Women Architects in Portugal: Working in Colonial Africa before the Carnation Revolution (1950-1974)». Arts 9 (3): 86. DOI: https: / / doi.org/10.3390/arts9030086

Pedrosa, Patrícia Santos. 2010. Habitar em Portugal nos Anos 1960: Ruptura e Antecedentes. Um caminho pelo interior do discurso. PhD Thesis, ETSAB - Barcelona School of Architecture. 2015. «Women architects in Portugal. A long and winding road». In ArquitectAs. Redefiniendo la Professión, edited by Núria Álvarez Lombardero, 99-112. Sevilla: Recolectores Urbanos.

. 2019. «The W@ARCH.PT as an Ongoing Feminist Research Project in Architecture: Contextualizing Initial Reflections». The Plan Journal 4 (2): 4/2/1-4/2/12. DOI: https:/ / doi.org/10.15274/tpj.2019.04.02.7

Pérez-Moreno, Lucía and Patrícia Santos Pedrosa. 2020. «Women Architects on the Road to an Egalitarian Profession - The Portuguese and Spanish Cases». Arts 9 (1): 40. DOI: https: / / doi.org/10.3390/arts9010040.

Pimentel, Irene Flunser. 2011. A cada um o seu lugar, a política feminina do Estado Novo. Lisbon: Temas e Debates and Círculo de Leitores.

Pimentel, Irene Flunser, and Helena Pereira de Melo. 2015. Mulheres Portuguesas. História de Vida e dos Direitos das Mulheres num Mundo em Mudança. Lisbon: Clube do Autor.

Portas, Nuno. 1964. Estudos das Funções e da Exigência de Área da Habitação. Volume I - Necessidades familiares e áreas da habitação. Análise de exigências por funções, da habitação. Lisbon: LNEC.

Portas, Nuno (coord). 2003-2011. Políticas Urbanas. 2 Vol. Lisbon: Fundação Calouste Gulbenkian.

Portas, Nuno, and Luz Valente-Pereira. 1967. Inquérito piloto sobre necessidades familiares em matéria de habitação: 2o. relatório. Vol. 2. Lisbon: LNEC.

Roxo, Joana. 2016. A Senhora Arquiteto - Maria José Estanco. A cidade, o Porto e a arte: Residências artísticas em Sines. Master Thesis in Architecture, ISCTE-UL, Lisbon.

Tavares, Manuela. 2011. Feminismos. Percursos e Desafios (1947-2007). Lisbon: Leya.

Valente-Pereira, Luz. 1968. «As casas que se constroem». Diário de Lisboa, no. 16393, Year 48, August 8, 3rd edition, Suplemento literário, 4-6. Lisbon: Fundação Mário Soares/ DRR - Documentos Ruella Ramos. Available at http: / / casacomum.org/cc/visualiza dor?pasta $=06590.128 .22590 \# ! 24$

1971a. Organização e qualidade do espaço urbano: cidade: conceitos e definições. Lisbon: LNEC. 
. 1971b. Organização e qualidade do espaço urbano: modelo de análise dinâmica do sistema urbano à escala de zona urbana. Lisbon: LNEC.

. 1971c. Organização e qualidade do espaço urbano: inquérito piloto à utilização da cidade: preparação do inquérito e colecta de dados. Vol. 1. Lisbon: LNEC.

. 1971d. Organização e qualidade do espaço urbano: inquérito piloto à utilização da cidade: método, plano de análise e análise de dados. Vol. 2. Lisbon: LNEC.

. 1973. «Modelo do Sistema Urbano à Escala de Zona Urbana». Análise Social X (37):

5-49. JSTOR: www.jstor.org/stable/41008101.

. 1977a. Inquérito à habitação urbana: o uso e o espaço dos fogos. Vol. 1. Lisbon: LNEC.

. 1977b. Inquérito à habitação urbana: o uso e o espaço dos fogos. Vol. 2. Lisbon: LNEC.

1977c. Inquérito à habitação urbana: o uso e o espaço dos fogos. Vol. 3. Lisbon: LNEC.

. 1981a. «O espaço urbano como objecto arquitectónico - consequências a nível do planeamento, do projecto e das práticas profissionais». In $2 .^{\circ}$ Congresso da Associação dos Arquitectos Portugueses: Os Arquitectos e o Ordenamento do Território, edited by Associação dos Arquitectos Portugueses, 121-124. 1st ed. Lisbon: AAP.

. 1981b. A estrutura da informação de base local no contex to da descentralização e regionalização. Lisbon: CIUR.

. 1982. Definição da forma urbana no planeamento físico. Scientific work M 570. Memories. Lisbon: LNEC.

1983a. Forma urbana no planeamento físico. Lisbon: LNEC.

1983b. Os equipamentos colectivos e a transformação urbano-rural. Scientific work M 586.

Memories. Lisbon: LNEC.

. 1984a. Metodologia do planeamento municipal: bases para a renovação da metodologia do planeamento. Vol.1. Lisbon: LNEC.

.1984b. Metodologia do planeamento municipal: os estudos sumários do planeamento: política e estratégia da acção municipal. Vol. 2. Lisbon: LNEC.

. 1986a. Planeamento municipal e exercício da acção política local. Technical information ITE 10. Technical building information. Lisbon: LNEC.

. 1986b. Método de apoio técnico à acção de desenvolvimento sócio-urbanístico de uma área urbana de intervenção: metodologia, vol. 1. Technical information ITE 13. Technical building information. Lisbon: LNEC.

. 1987a. Arquitectura urbana - Métodos e critérios de projecto. Lisbon: LNEC.

. 1987b. Reabilitar o urbano ou como restituir a cidade à estima pública. Technical information ITE 16. Technical building information. Lisbon: LNEC.

. 1987c. Método de apoio técnico à acção de desenvolvimento sócio-urbanístico de áreas urbanas de intervenção: Planeamento e programação das intervenções a curto prazo, vol. 2. Technical information ITE 13. Technical building information. Lisbon: LNEC.

1990. A utilização da cidade: um estudo sobre a cidade de Lisboa. Scientific information INCGURPLAM 2. Municipal planning scientific information. Lisbon: LNEC.

. 1991. Metodologia de planeamento da reabilitação de áreas urbanas. Scientific information INCGURPLAM 4. Municipal planning scientific information. Lisbon: LNEC.

.1994. A leitura da imagem de uma área urbana como preparação para o planeamento-acção da sua reabilitação. Scientific information INCGURPLAM 12. Municipal planning scientific information. Lisbon: LNEC.

. 2018. «Um Testemunho de Vida-Mulher, Arquitecta, Investigadora / A Life TestimonyWoman, Architect, Researcher». In Arquitectas: Modo(s) de (R)Existir. Reflexões a partir de um Ciclo de Conversas, edited by Joana Pestana Lages, Patrícia Santos Pedrosa, and Lia Gil Antunes, 38-43. Lisbon: Mulheres na Arquitectura. 
. 2019. Interview with Luz Valente-Pereira in the scope of the research project W@ ARCH.PT - Women Architects in Portugal: Building Visibility, 1942-1986, Alenquer. Interviewed by Patrícia Santos Pedrosa and Lia Gil Antunes. Video and audio. December 20 .

. n.d. Urban Rehabilitation-The Reading of the Urban Image. Self-published. Available at https: / / issuu.com/luzvalente-pereiraurbanplanning/docs/the_reading_of_the_ urban_image_.

Valente-Pereira, Luz, and Maria Amélia B. Corrêa Gago. 1972. Inquérito à habitação urbana: pesquisa de campo. Lisbon: LNEC.

. 1974a. Inquérito à habitação urbana: análise e interpretação das actividades na habitação e a sua relação com os espaços da casa. Lisbon: LNEC.

. 1974b. Inquérito à habitação urbana: características da amostra. Lisbon: LNEC.

. 1974c. O Uso do espaço na habitação. Lisbon: LNEC. Disponível em https: / / www.aca demia.edu/7720855/O_USO_DO_ESPAÇO_NA_HABITAÇÃO.

Patrícia Santos Pedrosa. Feminist, architect, activist, professor, researcher, and mother. Researcher at the Interdisciplinary Centre for Gender Studies, University of Lisbon. Invited Assistant Professor at the University of Beira Interior. Co-founder and president of Women in Architecture (Portugal). Researcher in charge of the project Women Architects in Portugal: Building Visibility 2018-2021. Main areas of research: Architecture and Gender; Cities and Gender; Feminist Urbanism; Portuguese Architecture History ( $20^{\text {th }}$ century).

Endereço eletrónico: pat.pedrosa@gmail.com

Lia Gil Antunes. Architect, researcher, feminist, and co-founder of Mulheres na Arquitectura association. PhD candidate in darq-UCoimbra about women - architects, other professionals, and inhabitants - of the SAAL process, and research fellow in the project W@ARCH.PT - Women Architects in Portugal: building visibility, 1942-1986 (CIEG / ISCSP-ULisboa). Areas of interest: Feminist and gender studies; History and Theory of Architecture; Right to Housing and Right to the City; Citizen participation. Endereço eletrónico: liapantunes@gmail.com 
